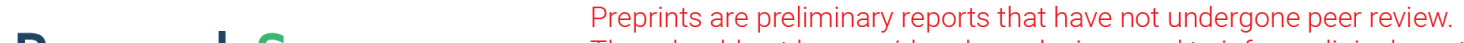 \\ They should not be considered conclusive, used to inform clinical practice, or referenced by the media as validated information. \\ Post COVID-19 Guillain Barre Syndrome in Immunocompromised Children - A report of two cases and review of literature
}

\section{Neha Goel}

Vardhman Mahavir Medical College and Safdarjung Hospital

\section{Sumit Mehndiratta}

Vardhman Mahavir Medical College and Safdarjung Hospital

Amitabh Singh ( $\square$ doc.amitabh@gmail.com)

Vardhman Mahavir Medical College and Safdarjung Hospital https://orcid.org/0000-0002-4440-5339

\section{Research Article}

Keywords: Covid-19, Guillain Barre Syndrome, Severe acute respiratory syndrome Coronavirus 2 (SARSCoV 2), children, acute leukemia

Posted Date: September 21st, 2021

DOl: https://doi.org/10.21203/rs.3.rs-922503/v1

License: (9) This work is licensed under a Creative Commons Attribution 4.0 International License. Read Full License 


\section{Abstract}

\section{Introduction}

Severe acute respiratory syndrome Coronavirus 2 (SARS-CoV 2) is a novel coronavirus that caused an outbreak since 31 December 2019. Although the most commonly noted symptoms were fever and respiratory illness, a wide variety of other symptoms have also been seen. There has been increasing number of cases of neurological manifestations of Covid -19. Further, there has been growing association between Covid-19 and Guillain Barre Syndrome (GBS).

\section{Case presentation}

In this report, we present two cases of acute lymphoblastic leukemia affected by Covid-19 who after recovery from Covid-19 developed symptoms of GBS. They presented with complaints of bilaterally symmetrical ascending motor paralysis and were diagnosed with Guillain Barre Syndrome by electrophysiological tests and were started on intravenous immunoglobins for five days @ $0.4 \mathrm{mg} / \mathrm{kg} / \mathrm{day}$ after which the condition of both children gradually improved.

\section{Conclusion}

This case report adds to the emerging evidence that suggests the association of GBS post Covid infections. COVID-19 can result in several autoimmune neurological phenomena including GBS. In the setting of the pandemic, COVID-19 as an underlying trigger should be considered in all immunologic phenomena. This applies to all patients, including children.

\section{Introduction}

Severe acute respiratory syndrome Coronavirus 2 (SARS-CoV 2) is a novel coronavirus that caused an outbreak since 31 December 2019. Although the most commonly noted symptoms were fever and respiratory illness, a wide variety of other symptoms have also been seen ${ }^{1}$. There has been increasing number of cases of neurological manifestations of Covid - 19. Further, there has been growing association between Covid-19 and Guillain Barre Syndrome (GBS). In this report, we present two cases of acute lymphoblastic leukemia affected by Covid-19 who after recovery from Covid-19 developed symptoms of GBS.

\section{Case 1}

A three-year-old boy, a diagnosed case of B-cell ALL (acute lymphoblastic leukemia) with BCR-ABL positivity presented in the emergency with symptoms of acute onset gradually progressive symmetric ascending lower limb weakness. Neurological manifestations of the patient started with acute progressive weakness of the distal portion of distal lower extremities that gradually progressed to involve the proximal portion of the distal lower extremities over a period of two days before admission. He did not 
have any bladder or bowel involvement or cranial nerve palsies. The patients developed cough and fever two weeks back when he was diagnosed with COVID-19 infection after examining nasopharyngeal and oropharyngeal sampling. Reverse transcription-polymerase chain reaction (RT-PCR) for COVID-19 was positive. The patient was managed as per COVID-19 treatment protocol of the institution. On physical examination, the child was afebrile with stable vitals and normal blood pressure. The patient was conscious and had no dyspnea at time of admission. The muscle strength examination showed weakness in lower limbs with a Medical Research Council (MRC) scale of $>4 / 5$ in proximal and distal upper limbs, 3/5 in proximal lower limb, 2/5 in distal lower limb. Deep tendon reflexes were absent in lower limbs. Sensory and autonomic examination were within normal limits with no cranial nerve involvement. There were no signs of meningeal irritation. Laboratory investigations including hemograms, electrolytes, kidney function and liver function tests were within normal limits. Nerve conduction studies demonstrated motor neuropathy affecting both upper and lower limbs. The patient was managed with $0.4 \mathrm{~g} / \mathrm{kg} /$ day intravenous Immunoglobin for a duration of five days after which the condition gradually improved.

\section{Case 2}

The second case was a three-year-old boy, a diagnosed case of B-cell ALL on interim maintenance who presented with complaints of not being able to walk for two days. Neurological examination showed gradually progressive weakness of bilateral lower limbs which was acute in onset. Initially it involved the distal part of lower limb which gradually progressed to involve the proximal part of lower limb as well. There was no bowel or bladder involvement or cranial nerve palsy. SARS-CoV2 antibodies of the patient were found to be positive. On physical examination, the child was hemodynamically stable, afebrile and vitally stable. The muscle strength examination showed weakness in lower limbs with a Medical Research Council (MRC) scale of $>4 / 5$ in proximal and distal upper limbs, 3/5 in proximal lower limb, 2/5 in distal lower limb. Deep tendon reflexes were absent in lower limbs. Sensory and autonomic examination were within normal limits with no cranial involvement. Meningeal irritation signs and upper motor neuron disorder signs were negative. Laboratory investigations showed normal hemogram, electrolytes, renal and liver function test. Nerve conduction studies showed motor neuropathy involving lower limbs. The child was managed with intravenous immunoglobin @0.4g/ $\mathrm{kg} /$ day for a period of five days after which the power of lower limbs showed minimum improvement. He required a second course of intravenous immunoglobulins when he showed further worsening with bulbar involvement in the form of a nasal twang of voice and neck flop. These newer symptoms improved with the second course of IVIG but the lower limb weakness persisted and required ankle-foot orthosis.

\section{Discussion}

In this study, we reported Guillain Barre Syndrome in two patients infected with Covid-19. The first ever case of novel coronavirus (Covid-19) was noted in Wuhan City, Hubei Province of China. It is a new beta coronavirus that gains access inside the cell by binding with angiotensin- converting enzyme 2 (ACE2) receptor. Covid 19 can cause variety of symptoms, amongst which respiratory complications similar to 
severe acute respiratory complications are mostly seen that include fever, cough, dyspnea, myalgia and headache.

Besides respiratory system involvement, other systems are known to be involved that produces symptoms such as diarrhea, gastrointestinal complications, acute cardiac damage and acute renal failure.

Coronavirus is a neurotropic and neuroinvasive virus that stimulates inflammatory cells that leads to production of various inflammatory cytokines creating an immune mediated process. GBS being an immune mediated disorder can be caused by molecular mimicry.

The neurologic manifestations of COVID-19 span a large spectrum ranging from anosmia, ageusia, encephalopathy, encephalitis, myelitis to post infectious complications like Guillain Barre Syndrome (GBS), plexopathies and cranial neuropathies ${ }^{2}$.

One postulated route for entry of Severe Acute Respiratory Syndrome Coronavirus 2 infection (SARSCoV2) into the central nervous system (CNS) is trans-synaptic travel from the olfactory epithelium 3. The entry into the CNS is mediated by the endothelial ACE2 (angiotensin-converting enzyme 2) receptors in brain vessels ${ }^{4}$. The haematogenous route is another source of spread to the $\mathrm{CNS}^{5}$. In these cases, the virus is probably introduced into the CNS via a leaky blood brain barrier.

However, in the cases of GBS reported by Dalakas et al, among the 7/11 patients tested, there was no virus detected in the cerebrospinal fluid, thus ruling out direct infection of the roots ${ }^{2}$. Thus, the pathogenesis is most likely immune mediated. GBS has been described with several infectious agents in the past. The commonly reported viruses are influenza, cytomegalovirus, Ebstein-Barr virus, herpes simplex virus, enteroviruses, hepatitis viruses and HIV ${ }^{2}$. GBS has previously been reported with other coronaviruses $^{6}$. One study described an increased incidence of GBS at their centre during the COVID-19 pandemic ${ }^{7}$, but this has not been seen by others ${ }^{8}$.

Several case series of adult patients have been published over the course of the ongoing COVID-19 pandemic. Some of them are listed below (Table 1). Data on children is scanty. 
Table 1

Summary of case series of patients of Covid-19 with neurologic manifestations

\begin{tabular}{|c|c|c|c|}
\hline $\begin{array}{l}\text { S } \\
\text { no }\end{array}$ & Authors & Cases & $\begin{array}{l}\text { Additional } \\
\text { Comments }\end{array}$ \\
\hline 1 & $\begin{array}{l}\text { Toscano } \\
\text { and } \\
\text { colleagues } \\
\text { (9) } \\
\text { (Italy) }\end{array}$ & $\begin{array}{l}\text { Treated five patients with GBS after onset of COVID-19 } \\
\text { disease. All of them were treated with IVIG; two of them } \\
\text { needed a second course of IVIG and one also needed to be } \\
\text { started on plasma exchange. }\end{array}$ & $\begin{array}{l}\text { The need for a } \\
\text { second course } \\
\text { of IVIG is } \\
\text { similar to the } \\
\text { course of one } \\
\text { of our } \\
\text { patients. }\end{array}$ \\
\hline 2 & $\begin{array}{l}\text { Paterson et } \\
\text { al (10) } \\
\text { (London) }\end{array}$ & $\begin{array}{l}\text { Reported } 43 \text { cases (ages } 16-85 \text { years) with COVID- } 19 \text { related } \\
\text { neurologic disorders. Of these seven were cases of GBS. All } \\
\text { of them received IVIG and the majority showed partial and } \\
\text { ongoing recovery. }\end{array}$ & $\begin{array}{l}\text { Case } 2 \\
\text { showed partial } \\
\text { recovery }\end{array}$ \\
\hline 3 & $\begin{array}{l}\text { Frontera } \\
\text { and } \\
\text { colleagues } \\
\text { (11) } \\
\text { (New York } \\
\text { City) }\end{array}$ & $\begin{array}{l}\text { Described } 606 \text { cases (ages } 57-83 \text { years) with neurologic } \\
\text { disorders in patients hospitalized with SARSCoV2 infection. } \\
\text { Three of these cases had GBS. }\end{array}$ & \\
\hline 4 & $\begin{array}{l}\text { In the } \\
\text { French } \\
\text { NeuroCOVID } \\
\text { registry (12) }\end{array}$ & $\begin{array}{l}\text { Among the } 222 \text { patients with neurologic manifestations of } \\
\text { Covid- } 19 \text { (age } 53-72 \text { years) GBS was seen in } 15 \text {. Fourteen of } \\
\text { these were treated with IVIG and two required mechanical } \\
\text { ventilation. }\end{array}$ & \\
\hline 5 & $\begin{array}{l}\text { CoroNerve } \\
\text { study group } \\
\text { (13). } \\
\text { (United } \\
\text { Kingdom) }\end{array}$ & $\begin{array}{l}\text { In a United Kingdom-wide surveillance study conducted by } \\
\text { the CoroNerve study management group, neurological and } \\
\text { neuropsychiatric complications of COVID- } 19 \text { in } 153 \text { patients } \\
\text { were studied (age range } 23-94 \text { years). Out of these, four } \\
\text { patients were diagnosed to be suffering from GBS and its } \\
\text { variants. }\end{array}$ & \\
\hline
\end{tabular}

Both the cases reported by us had classic symptomatology of GBS, and case 1 presented almost two weeks after Covid - 19. The latency of disease onset cannot be ascertained in case 2 because he had no initial manifestations of Covid-19.

Many patients with GBS do not have any COVID-19 symptoms at presentation ${ }^{2}$. Dalakas et al suggest that the diagnosis should be especially suspected in cases with anosmia, ageusia, cranial neuropathies, or lymphocytopenia. The latent period between onset of symptoms of COVID-19 and the onset of GBS has also been variable. Some researchers have reported an earlier than usual onset of symptoms following infection ${ }^{9,14,15}$ while others have described a more typical latent period ${ }^{8}$.

\section{Conclusion}

This case report adds to the emerging evidence that suggests the association of GBS post Covid infections. COVID-19 can result in several autoimmune neurological phenomena including GBS. In the 
setting of the pandemic, COVID-19 as an underlying trigger should be considered in all such phenomena. This applies to all patients, including children, and should be considered in children with co-morbidities too.

\section{Declarations}

Funding - none

Conflicts of interest/ competing interests - none

Ethics approval - obtained from institute ethics committee IEC/VMMC/SJH/2020-08/CC-42

Consent to participate - obtained from legal guardian

Consent for publication - obtained from legal guardian

Availability of data and material (data transparency) - reported data available for review

Code availability (software application or custom code) - not applicable

Authors' contributions - NG, SM, \& AS participated in conception of study, analysis and interpretation of data, drafting the article or revising it critically for important intellectual content and all authors approved the final version.

\section{References}

1. Wiersinga WJ, Rhodes A, Cheng AC, Peacock SJ, Prescott HC. Pathophysiology, Transmission, Diagnosis, and Treatment of Coronavirus Disease 2019 (COVID-19): A Review. JAMA. 2020;324(8):782-93.

2. Dalakas MC. Guillain-Barré syndrome: The first documented COVID-19-triggered autoimmune neurologic disease: More to come with myositis in the offing. Neurol Neuroimmunol Neuroinflamm. 2020;7(5):e781.

3. Bodro M, Compta Y, Sánchez-Valle R. Presentations and mechanisms of CNS disorders related to COVID-19. Neurol Neuroimmunol Neuroinflamm. 2020;8(1):e923.

4. Desforges M, Le Coupanec A, Dubeau P, Bourgouin A, Lajoie L, Dubé M, et al. Human Coronaviruses and Other Respiratory Viruses: Underestimated Opportunistic Pathogens of the Central Nervous System? Viruses. 2019;12(1):14.

5. Desforges M, Le Coupanec A, Brison E, Meessen-Pinard M, Talbot PJ. Neuroinvasive and neurotropic human respiratory coronaviruses: potential neurovirulent agents in humans. Adv Exp Med Biol. 2014;807:75-96.

6. Wakerley BR, Yuki N. Infectious and noninfectious triggers in Guillain-Barre syndrome. Expert Rev Clin Immunol. 2013;9:627-39. 
7. Gigli GL, Bax F, Marini A, Pellitteri G, Scalise A, Surcinelli A, et al. Guillain-Barré syndrome in the COVID-19 era: just an occasional cluster? J Neurol. 2021;268(4):1195-7.

8. Assini A, Benedetti L, Di Maio S, Schirinzi E, Del Sette M. New clinical manifestation of COVID-19 related Guillain-Barrè syndrome highly responsive to intravenous immunoglobulins: two Italian cases. Neurol Sci. 2020;41(7):1657-8.

9. Toscano G, Palmerini F, Ravaglia S, Ruiz L, Invernizzi P, Cuzzoni MG, et al. Guillain-Barré Syndrome Associated with SARS-CoV-2. N Engl J Med. 2020;382(26):2574-6.

10. Paterson RW, Brown RL, Benjamin L, Nortley R, Wiethoff S, Bharucha T, et al. The emerging spectrum of COVID-19 neurology: clinical, radiological and laboratory findings. Brain. 2020;143(10):3104-20.

11. Frontera JA, Sabadia S, Lalchan R, Fang T, Flusty B, Millar-Vernetti P, et al. A Prospective Study of Neurologic Disorders in Hospitalized Patients With COVID-19 in New York City. Neurology. 2021;96(4):e575-86.

12. Meppiel E, Peiffer-Smadja N, Maury A, Bekri I, Delorme C, Desestret V, et al. contributors to the NeuroCOVID registry. Neurologic manifestations associated with COVID-19: a multicentre registry. Clin Microbiol Infect. 2021;27(3):458-66.

13. Varatharaj A, Thomas N, Ellul MA, Davies NWS, Pollak TA, Tenorio EL, et al. CoroNerve Study Group. Neurological and neuropsychiatric complications of COVID-19 in 153 patients: a UK-wide surveillance study. Lancet Psychiatry. 2020;7(10):875-82.

14. Gutiérrez-Ortiz C, Méndez-Guerrero A, Rodrigo-Rey S, San Pedro-Murillo E, Bermejo-Guerrero L, GordoMañas R, et al. Miller Fisher syndrome and polyneuritis cranialis in COVID-19. Neurology. 2020;95(5):e601-5.

15. Ottaviani D, Boso F, Tranquillini E, Gapeni I, Pedrotti G, Cozzio S, et al. Early Guillain-Barré syndrome in coronavirus disease 2019 (COVID-19): a case report from an Italian COVID-hospital. Neurol Sci. 2020;41(6):1351-4.

\section{Supplementary Files}

This is a list of supplementary files associated with this preprint. Click to download.

- CAREchecklistEnglish2013converted1.docx 